\title{
The Contribution of M. Isa in the Physical Revolution Period (1945-1949)
}

\author{
Fitri Khotijah', Sardiman ${ }^{2}$ \\ 1,2Yogyakarta State University, Yogyakarta, Indonesia \\ ${ }^{1}$ Fitrikhotijah224@gmail.com, ${ }^{2}$ Sardiman@uny.ac.id
}

\begin{abstract}
The Indonesian people struggle, especially South Sumatra in seizing and maintaining the Independence of the Republic of Indonesia, involved many figures and people of South Sumatra. One of the best figures in South Sumatra who contributed a lot in the struggle for Indonesian independence was Mohamad Isa or commonly called M.Isa. He is one of the figures who fought against colonialism. This paper reveals how M.Isa played his role in the early days of the independence of the Republic of Indonesia and during the physical revolution of 1945-1949 or the War of Independence. Based on the analysis of M.Isa's activities during the War of Independence, it can be said that M.Isa has an important role. He is a civilian figure who contributes as a government administrator. M.Isa collaborated with A.K.Gani and Abdul Rozak who were three inseparable figures in the struggle during the early days of independence, and the struggle to defend the independence of the Republic of Indonesia in South Sumatra.
\end{abstract}

Keywords : M.Isa, Physical Revolution Period

\section{Introduction}

The proclamation of Indonesian independence on August 17, 1945 is inseparable from the struggle of the Indonesian people. Indonesian independence is not approved by some Japanese soldiers due to agreements with allies to maintain the status quo in occupied territories. Besides the undermining came from the Dutch who wanted to colonize Indonesia. The struggle of the Indonesian people in 1945-1949 was called a revolution. The term revolution is used to describe breakthroughs for better, realignment of people's lives by the community in a direction that is generally seen as better than before.

The concept of this revolution is relevant to describe the events that occurred in Indonesia in 1945-1949, where the Indonesian people fight together to organize the life of the nation in a better direction, namely by remove colonialism to realize national independence [1]. The struggle during the revolution for independence aims to maintain independence. In fighting for independence the youth also played a role in fighting the invaders. In the history of the Indonesian nation, the revolution that ever happened was a physical revolution, this revolution is a phase of the struggle to get out of the grip of the invaders. This phase involved many groups, especially young people who became the driving force of the revolution[2].

The struggle against the invaders also took place in Palembang that is one of the regions in the archipelago region historically showing very long historical developments. Palembang is 
part of Indonesian territory that was involved in the war. The area of Palembang residency is as broad as that is now in the province of South Sumatra. This vast area has the potential for natural resources such as petroleum, gold and coal. This became one of the reasons for the Dutch to control this area. On the other hand, the desire of the Indonesian people generally and South Sumatra in particularlly to maintain their territory as an independent region that causes conflict with the Dutch who want to recolonize.

One figure who is persistent against the invaders is Dr. M. Isa. He has devoted in developing South Sumatra since the colonial period in the Netherlands. In this paper we will discuss how the role of Dr. M. Isa in the struggle against the invaders during the Physical Revolution in Palembang.

\section{Method}

Learning history can be implemented and used material of moral instruction, and history is also a teacher of the lessons of today and here after [4]. History must br part of the knowledge and science of man [5]. History as science has its own method of revealing a past event in order to result in critical, scientific and objective writing of history. Research methods are essentially a scientific, data, purpose and usefulness. The scientific way means that research is based on human, rational, empirical, and systematic characteristics [6].

The method used in this study is the historical method. Historical methods according to Kuntowijoyo are self described from the five stages of topic selection, source search and collection (heuristic), source criticism (verification), interpretation and historical writing (historiography). If historical methods are relevant to the process of tracing historical sources to the fact of history and its design in historical writings, then the methodology of history is the science that further asks for the truth of the method [7]. On the basis of this, the writer has used historical research methods and qualitative data analysis techniques.

\section{Result And Discussion}

Palembang Residency is divided into three groups, each of which is headed by a resident assistant, and each group is divided into several parts that are headed by a controller [8]. According to Ricklefs the period of physical revolution in the belief of many parties is considered an age that is a continuation of the past. For the leaders of the Indonesian revolution the aims to complete and perfect the process of national unification and revival which has begun four decades earlier [9].

\subsection{Isa Figure}

M Isa Is a warrior figure who contributes in developing South Sumatra during the independence and physical revolution (1945-1949). M. Isa was born in Binjai on 4 June 1909 and died on 7 November 1979. He was the fourth child of Datuk Haji Ismail from his wife named Zainab.His father was Datuk Haji Ismail who served as the Head of the Week or head of market affairs besides his main profession as a teacher in an elementary school. M.Isa grew up from a religious family, he already read the Koran when he was still in elementary school 
or HIS level. M.Isa has a fairly good educational background, starting from HIS, then continuing to MULO and AMS. After that he completed his education at STOVIT to get the title of drg (dentist) [10]. M.Isa studied in Java, he often discussed with Dr. Soetomo so he joined Parindra (Partai Indonesia Raya) and once a lecturer assistant because of his academic intelligence. In 1938, he decided to quit as a teaching assistant and chose to move to Palembang to become a private doctor.

The ability of Dr. M. Isa as a civil leader in coordinating various fields such as government, oil, plantation, labor, finance, to making weapons gives him an important position and is considered nationally then he was appointed as an expert from the Republic of Indonesia delegation to the Conference Conference Round (KMB) on August 31, 1949.

\subsection{M.Isa as South Sumatra Governor}

The formation of Indonesia can be distinguished into two processes, namely nation building and state development, Indonesian nation as an "imagined society" has begun to form during the colonial period, especially by the development of nationalism, while the process of national development refers more to the formation of administrative unity, governance, and legislation [11].

The proclamation of independence received full support from the Indonesian people including South Sumatra. News of the proclamation which was initially received in secret, then developed clearly a few days later. The independence information attracted the attention of local community leaders in this area to immediately close ranks and face all the possibilities that will occur after the independence proclamation.

On September 3, 1945 the South Sumatra Regional Committee (KNID) was formed with AKGani appointed as chairman who was soon replaced by M.Isa and on September 25, 1945 M.Isa got an assignment as a deputy of the Prosperity Service chaired by Ir.Ibrahim Zahir in the structure of the Palembang Residency. He also served as chairman of the Republic of Indonesia Oil Company (PERMIRI) and on 12 April 1946 formed the Republic of Indonesia Plantation Labor Union (SERBUPRI). His efforts to fight for independence were carried out by adopting strategic policies such as supporting the production of home weapons and printing money from Curup to beat the Netherlands in fiscal terms.

On August 24, 1945 by boarding Japanese airplane, representatives of Sumatra arrived at the Indonesian Independence Preparatory Committee in Jakarta, namely Dr.Amir, Mr.Teuku Muhammad Hasan and Mr.Abbas. in a meeting held between three delegates from Jakarta and regional leaders in South Sumatra namely Dr.AKGani, Dr.M.Isa, Assari, Ir.Ibrahim, Mursodo, RZ.Fanani, Abdul Rozak and Nungjik AR, discussed the proclamation issue August 17, 1945 by representatives of the Indonesian people Soekarno-Hatta. The results of the meeting include [12]:

a) Proclamation has nothing to do with Japan

b) The Provisional Constitution was adopted by the Preparatory Committee for the Preparation for Independence in Palembang on 18 August 1945

c) Composition of the Indonesian National Committee

d) Council of Ministers

e) People's Security Guard

f) Business and ways of taking over government from the hands of Japan.

In South Sumatra, the power struggle took place on October 8, 1945, when leaders and all Gunseibu employees in a ceremony hoisted the Red and White flag. On that day it was also announced that the Palembang Residency had only one power, namely the Republic of 
Indonesia. The power struggle in Palembang took place without incident because the Japanese people had avoided the demonstrations [13].

The Japanese defeat of the Allies made the Dutch return and had been in Palembang since October 24, 1946. Initially the arrival of the Allied forces was not suspected by the Republic of Indonesia, because earlier on October 5, 1945 Dr.AK.Gani received a telegram from the KNIP stating the arrival of the Allies and was declared that the Allies recognized de facto the territory of the Republic of Indonesia as a newly independent country and promised not to allow the Dutch to bring in its troops. On this basis Dr.A.K.Gani gave permission to the Allied troops to find a location in Talang Semut.

While in Palembang, the Netherlands had many opportunities to strengthen its position. Under the leadership of Mr.M.J.Wimolen, the Netherlands tried to establish a civilian government by bringing in the Dutch army under Colonel Molinger's army. Seeing the Dutch action, the Indonesian side did not remain silent, because the Dutch action endangered the Republican Government. To deal with all the possibilities that could happen, then strength was arranged to defend the Republican Government. In the end of the battle erupted for 5 days 5 nights, starting on January 1, 1947 that was rated as the largest battle in the city of Palembang during the Physical Revolution [14].

On January 1, 1948 the enactment of the deputy prime minister on behalf of the President of the Republic of Indonesia issued an announcement containing a decree stating that to honorably dismiss M.Isa as commissioner of the South Sumatra government, then dismiss South Sumatra Military Governor Dr.AKGani and appoint M.Isa became the regional head with the rank of Governor of South Sumatra Province [10]. Previously dr.A.K.Gani who served as Military Governor of South Sumatra II [15]. On April 15, 1948, the status of South Sumatra as a Sub-Province was upgraded to the province. When Bung Karno was in Lubuklinggau, a ceremony was held to inaugurate the appointment of Dr.Isa. other groups [16].

The Young Governor is domiciled in Curup, Bengkulu, and arranges the government. When in Curup, the Renville Agreement was reached with the approval of a demarcation line that separated Indonesian territory and the occupied territories of the Netherlands. For the Palembang Residency there were areas occupied by the Netherlands, in fact these areas were not really occupied, however the government in South Sumatra had to surrender the area to the Netherlands in accordance with the contents of the Renville Agreement [17].

\subsection{M.Isa Contribution}

When the Japanese entered Palembang since February 1942, not long afterwards many Palembang prominent figures were suspected and then arrested and tortured by the Japanese, including dr.A.K.Gani, M.Isa. In 1944 Japan formed the "Voluntary Line" or the so-called Gyugun, M.Isa encouraged young people to participate in the recruitment of Gyugun. After the independence of the Republic of Indonesia on August 17, 1945. Indonesian people were immediately confronted with the problem of maintaining the newly achieved independence from the threat of invaders who sought to regain Indonesia. The Dutch attitude towards the Proclamation of Indonesian independence assumed that Indonesia was not yet independent. With Japan's defeat of the allies, the Dutch returned to Indonesia to take control by piggybacking on the Allied forces who disarmed the Japanese Army in Indonesia.

On July 21, 1947 the Dutch attacked Indonesia from land, sea and air, known as Dutch Military Aggression II [18]. For the Palembang residency began in January 1949. The Netherlands tried to occupy areas of the Republic of Indonesia and cities that are considered 
strategic, in order to expand its power to be able to re-colonize Indonesia. When the Five-DayFive-Night War took place in 1947, M.Isa as regional leader agreed to a ceasefire while still taking into account the people's safety and the continued struggle. He chose to continue the struggle outside the city of Palembang since December 20, 1947, then moved from Lubuklinggau to Curup. Guerilla War requires the support of various groups of people including the common people in the countryside, therefore efforts to unite the various powers that exist in society need to be done. Through an instruction, the Military Governor called on the TNI, members of the civil service, socio-political organizations, and the general public to unite against the Dutch enemy [19].

Governor M. Isa and Colonel Simbolon Commander of the South Sumatra Army joined the Indonesia National Armed Force from South Sumatra who came to the Bukit Barisan area around Merangin. May 19, 1949 a government group from South Sumatra visited Muara Bungo consisting of Army Commander Colonel Simbolon, deputy military governor / Governor M.Isa, South Sumatra police commissioner, Hasan and others. Then there were meetings and deliberations several times concerning government and national defense [20].

In its development, M. Isa, who came from the Indonesian Nationalist party, had a relationship with the Garuda Council. The formation of the Garuda Council in South Sumatra began with an adat congress held in Palembang from 15 to 17 January 1957 which issued a charter for the struggle of the people of South Sumatra. M.Isa established good relations with the army so that the movement on the Garuda Board was easily read by the central government. Since then, the internal Garuda Board experienced a fraction of some of its members establishing communication with the central government and partly supporting the existing struggle in Sumatra where these conditions made the trust of members who are members of the Palembang charter began to experience a decrease in trust [21].

The journey and struggle in facing the Netherlands was faced with unyielding spirit even though the offer to join or cooperate with the Netherlands was always given by the Dutch. Struggle and governance arrangements carried out in guerrilla by military and community leaders. This shows a reflection of civil and military unity in defending the prominance of the state [22].

\section{Conclusion}

Throughout his career M.Isa has occupied various position, including the Governor of South Sumatra, the Resident chairman of the Republic of Indonesia Oil Company (PERMIRI) and formed the Republic of Indonesia Plantation Labor Union (SERBUPRI). Naturally, if the position is considered nationally until the government sends M.Isa in the KMB negotiations. Thus, from the above review it is expected that the Indonesian people in general and South Sumatra in particular not only recognize heroes by name, but must try to explore the role of the warrior figures who have contributed in the struggling for Indonesian independence.

\section{References}

[1] Limah et.al. Poster dan Upaya Mempertahankan Kemerdekaan Indonesia di Yogyakarta Tahun 1945-1949. Journal of Indonesian History 7, no.1, pp.36 (2018) 
[2] Nawiyanto, Eko Crys Endrayadi; Kesultanan Palembang Darussalam Sejarah dan Warisan Budaya, Jember: Tarutama Nusantara, (2016)

[3] Ekaputri. Kapas dan Ekonomi Penduduk Keresidenan Palembang (Pertengahan Abad XIX-Awal Abad XX). Lembaran Sejarah. vol.4.no.1, pp.30 (2001)

[4] Kuntowijoyo. Metodolologi Sejarah. Yogyakarta: PT.Tiara Wacana Yogya, (2008)

[5] Kochhar. Teaching Of History. Jakarta: Grafindo, (2008)

[6] Sugiyono. Metode Penelitian Kombinasi. Bandung:Alfabeta, (2012)

[7] Wasino, Endah. Metode Penelitian Sejarah Dari Riset Hingga Penulisan. Yogyakarta: Magnum Pustaka Utama, (2018)

[8] Ayuningtyas, Sodiq. Perjuangan Panglima Besar Jenderal Soedirman pada Masa Revolusi Fisik Tahun 1945-1950. Journal of Indonesian History 5, no.1, pp.15 (2016)

[9] Yuarsa. Mohamad Isa, Pejuang Kemerdekaan yang Visioner. Jakarta: PT.Gramedia Pustaka Utama. (2016)

[10] Bemmelen, Raben. Antara Daerah dan Negara Indoneisa Tahun 1950-an. Jakarta: Pustaka Obor Indonesia, (2011)

[11] Abdullah et.al. Sejarah Daerah Sumatera Selatan. Palembang, Palembang: Departemen Pendidikan dan Kebudayaan Bagian Proyek Investasi dan Pembinaan Nilai-Nilai Budaya Provinsi Sumatera Selatan, (1991/1992)

[12] Poesponegoro. Sejarah Nasional Indonesia VI. Jakarta : Balai Pustaka., (2010)

[13] Chaidir. Kutitipkan Padamu Hai Anak Bangsa. Yogyakarta: Deepublish, (2019)

[14] Toer et.al. Kronik Revolusi Indonesia Jilid V (1949). Jakarta: Kepustakaan Populer Gramedia, (2014)

[15] Ajisaka. Mengenal Pahlawan Indonesia. Yogyakarta: PT.Kawan Pustaka, (2004)

[16] Toer dkk. Kronik Revolusi Indonesia Jilid VI. Jakarta: Kepustakaan Populer Gramedia, (2003)

[17] Kementerian Penerangan. Republik Indonesia Propinsi Sumatera Selatan. Indonesia: Kementerian Penerangan: (1954)

[18] Saelan. Kesaksian Wakil Komanda Tjakrabirawa: Dari Revolusi 45 Sampai Kudeta 66. Jakarta: Transmedia Pustaka, (2008)

[19] Hardi. Rakyat dan Revolusi. Yayasan Masyarakat Sejarawan Indonesia. Jurnal Sejarah vol.6, no.1, pp.25, (2004)

[20] Kementerian Penerangan. Propinsi Sumatera Tengah. Indonesia: Kementerian Penerangan, (1953)

[21] Dalilan, Mikail. Ijtihad Politik Islam Palembang di Masa Orde Baru. Jurnal Politik Profetik vol 6, no. 1,pp.44, (2018)

[22] Yusuf. Peran Residen Abdul Rozak Pada Masa Revolusi Fisik (1945-1949). Jurnal Criksetra, vol 5, no 9, pp.100 (2016) 